\title{
RELATO DE CASO: CESARIANA EM PORCA COM PROLAPSO DE VAGINA E TORÇÃO UTERINA
}

\author{
(Case Report: Cesarean in a Sow with Vaginal Prolapse and Uterine Torsion)
}

${ }^{1}$ Louise Krueger, ${ }^{1}$ Ivan Roque de Barros Filho, ${ }^{2}$ Letícia Andreza Yonezawa

\author{
${ }^{1}$ Universidade Federal do Paraná, Curitiba, Paraná, Brasil. '2Universidade do Estado de Santa Catarina, Santa \\ Catarina, Brasil.
}

*Correspondência: louisekrueger@hotmail.com

RESUMO: A incidência de prolapso de vagina em porcas é baixa e sua predisposição pode estar associada ao processo do parto (Supakorn et al., 2017), enquanto a torção uterina é rara e pode acarretar morte fetal (Prestes, 2017). O relato é de uma porca, matriz primípara, com parto previsto, porém não ocorrido. O proprietário observou prolapso da vagina, tentou desfazê-lo para retirada dos leitões e não obteve sucesso. No momento do atendimento pelo Médico Veterinário, o animal encontrava-se em posição quadrupedal e evidente prolapso de vagina. Na palpação transvaginal havia abertura de cérvix até certo ponto, suspeitando-se de torção uterina. Optou-se por cirurgia cesariana de emergência visando salvar a vida dos leitões. Foi realizada anestesia dissociativa com tiletamina e zolazepam $(3,6 \mathrm{mg} / \mathrm{kg})$ intravenosa. Em decúbito lateral direito, após depilação e antissepsia, foi realizada anestesia local utilizando cloridrato de lidocaína $(7 \mathrm{mg} / \mathrm{kg})$ na fossa paralombar esquerda, onde incisou-se a pele e musculatura de flanco esquerdo. O corno uterino esquerdo foi exposto e incisado, retirando seis leitões com vida. A sutura da incisão foi realizada em padrão ponto simples contínuo (PIS) e cushing sobrepondo. Repetiram-se os procedimentos no corno uterino direito retirando um leitão vivo e um feto mumificado. O colo do útero encontrava-se edemaciado e torcido cranial à cérvix, com rotação de 90 graus no sentido anti-horário, impedindo o parto. Desfez-se a torção uterina e reposicionou-se o útero, fechou-se a cavidade abdominal e o prolapso de vagina foi higienizado e reduzido. No pós-cirúrgico foram administrados enrofloxacina e piroxicam por via intramuscular (Zelotril Plus ${ }^{\circledR}-1 \mathrm{~mL} / 10 \mathrm{~kg}$ ). Recomendou-se ao proprietário administrar tulatromicina $(2,5 \mathrm{mg} / 40 \mathrm{~kg})$ no dia seguinte, realizar a limpeza da ferida cirúrgica até seu fechamento e o descarte da matriz da função reprodutiva. Aplicou-se pó secante nos leitões e estes mamaram o colostro. A porca recuperou-se totalmente. Além da influência dos hormônios associados ao parto (Supakorn et al., 2017), acredita-se que o prolapso de vagina foi consequência da torção uterina e do esforço sem sucesso da marrã no momento do parto. A torção uterina poderia ser consequência da assimetria dos cornos uterinos nesta gestação, pois um corno possuía seis e outros dois leitões em gestação. Como não havia sinais de necrose nos cornos uterinos, sugere-se que a torção era recente, o que condiz com Prestes (2017), que descreve que a torção uterina tende a ocorrer ao final da gestação. $O$ diagnóstico definitivo para esta afecção em suínos é por laparotomia exploratória (Prestes, 2017), como no caso relatado. A anestesia dissociativa utilizada foi eficiente, apesar do não cumprimento do período de jejum recomendado por se tratar de uma cirurgia emergencial. O tratamento ideal para o prolapso de vagina seria a sutura de Bühner (Supakorn et al., 2017), mas esta não foi realizada com receio de impedir a expulsão dos envoltórios fetais. A antibioticoterapia no póscirúrgico foi realizada para evitar uma infecção subsequente. Conclui-se que prolapso de vagina e torção uterina são afeç̧ões que podem ocorrer em porcas e que os procedimentos anestésicos e cirúrgico foram eficientes para salvas a vida dos leitões e marrã.

Palavras-chave: cesárea; suíno; marrã; cirurgia; parto

\section{Referências}

PRESTES, N.C. Distocias de Causa Materna. In: PRESTES, N.C.; LADIN-ALVARENGA, F.C. Obstetrícia Veterinária, 2ed. Rio de Janeiro: Guanabara Koogan, 2017. Cap. 13, p. 155-162.

SUPARKON, C.; STOCK, J.D.; HOSTETLER, C. et al. Prolapse Incidence in Swine Breeding Herds Is a Cause for Concern. Open Journal of Veterinary Medicine, v.7, p.85-97, 2017. 